\title{
Urban Narrators: Ruth Cardoso
}

\author{
Ana Luiza Carvalho da Rocha; Cornelia Eckert
}

\author{
Resumo \\ Episódio da série documental Narradores urbanos sobre a antropologia \\ urbana e etnografia nas cidades brasileiras. A antropóloga Ruth Cardoso \\ narra sua trajetória intelectual e a formação do campo de estudos da cultura \\ urbana no Brasil.
}

Palavras-chave: antropologia urbana brasileira, etnografia nas cidades brasileiras, trajetória intelectual, memória coletiva Keywords: Brazilian urban anthropology, Ethnography in Brazilian Cities, intellectual trajectory, collective memory 